\title{
Scholars and Literati at the Saint Petersburg Academy of Sciences (1724-1800)
}

\author{
David de la Croix \\ IRES/LIDAM, UCLouvain
}

\author{
Mehrdaad Doraghi \\ LIDAM, UCLouvain
}

This note is a summary description of the set of scholars and literati who participated in the activities of the Saint Petersburg Academy of Sciences, from its inception in 1724 to the eve of the Industrial Revolution (1800).

\section{The ACADEMY}

The Saint Petersburg Academy of Sciences, founded by Peter I the Great (1682-1725) in 1724, was an institution designed to bring the Russian Empire into the modern era. In fact, the Tsar had always been interested in science, promoting many scientific activities. During his travels in Europe, he visited the great centers of knowledge and the most illustrious scholars of the time. The purpose of these visits was also to become acquainted with the new ideas of the time and to apply them to the Russian industry. Among the scholars he met was the mathematician Leibniz, who in 1697 urged him to create an academy in Russia. This idea began to materialize only after he was appointed "honorary foreign member" of the Académie des Sciences in Paris and after meeting eminent scholars, including Christian Wolff, a professor of philosophy at the University of Halle (McClellan 1985). Unlike European countries where academies were formed around private associations or academic circles, this did not happen in the Russian Empire. For Peter the Great, the Russian Academy of Sciences was to be not only a research center, but also an institution for the training of future scientists and the diffusion of scientific knowledge, similarly to a university (Lipski 1953). When Peter I the Great died, his wife Catherine I who succeeded him called on the most important intellectuals in Europe to teach at the Academy. From 1728 onwards, academics published their scientific contributions in Latin each year under the title "Commentarii Academiae scientarum petropolitanae," which was of great interest abroad. In the eyes of the Russian aristocracy, who was skeptical of acquiring knowledge, the Saint Petersburg Academy of Sciences remained a foreign institution established in Russia. It became a more Russian institution hiring national scholars in the second half of the eighteenth century, with the involvement of Catherine II, the empress of Russia.

\section{SOURCES}

The main source is the book "General list of members of the Academy of Sciences since its foundation" by Shemivot (1873) (in Russian). It contains seven chapters listing domestic and foreign members of the Academy, as well as honorary members. Six out of the seven chapters contain members before 1800, and two of them list presidents and directors, the decision makers of the Academy.

\section{Some STATISTICS}

Table 1 shows some descriptive statistics. There are 324 scholars and literati, 32 during the first period. The year of birth is known for $95.7 \%$ of them. The mean age at appointment is 42.7 years. Our two measures of longevity, mean age at death and life expectancy at 30, display a marked increase over time. The birth place is known for $88.6 \%$ of the people. The median distance between 


\begin{tabular}{|c|c|c|c|c|c|c|}
\hline \multicolumn{2}{|c|}{ Period } & $\mathrm{nb}$. & $\%$ birth year & mean age & mean age & life exp. \\
\hline Start & End & obs & known & at appoint. & at death & at 30 \\
\hline 1686 & 1733 & 32 & 100 & 39.1 & 62.9 & 57.7 \\
\hline 1734 & 1800 & 292 & 95.2 & 43.1 & 65.9 & 60.3 \\
\hline 1000 & 1800 & 324 & $\overline{9} \overline{9} . \overline{7}$ & 42.7 & $\overline{6} \overline{5} . \overline{6}$ & 60 \\
\hline & & & $\begin{array}{c}\% \text { birth place } \\
\text { known }\end{array}$ & $\begin{array}{l}\text { median distance } \\
\text { birth-institution }\end{array}$ & $\begin{array}{c}\% \text { with } \\
\text { Wikipedia }\end{array}$ & $\begin{array}{c}\text { \% with } \\
\text { Worldcat }\end{array}$ \\
\hline 1686 & 1733 & & 96.9 & 1754 & 93.8 & 90.6 \\
\hline 1734 & 1800 & & 87.7 & 1593 & 91.8 & 88.7 \\
\hline 1000 & 1800 & & $88 . \overline{6}$ & 1600 & 92 & 88.9 \\
\hline
\end{tabular}

Table 1: Summary statistics by period

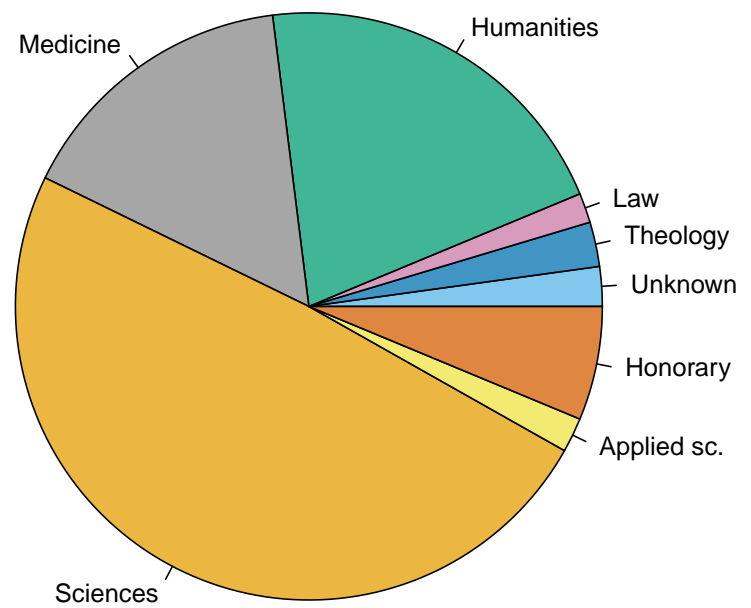

Figure 1: Broad fields at the Saint Petersburg Academy of Sciences

birth place and Saint Petersburg is $1,600 \mathrm{~km}$. This reflects how far scholars came from. $92 \%$ of the scholars have a Wikipedia page (in some language). $88.9 \%$ of them have left a footprint in the catalogues of the libraries of the world, Worldcat, either by having published some work, or by having been the subject of published books and articles. These percentages are quite high. The former is one of the largest with respect to other institutions.

\section{FIELDS}

Figure 1 shows the relative importance of fields, broadly defined. The distribution of fields highlights the primary division of fields at the Saint Petersburg Academy of Sciences between sciences and humanities, the latter being less important. In particular, sciences represent more than $50 \%$ of the scholars, while humanities and medicine represent $20 \%$ of them. The Academy also included some individuals classified as honorary, among whom presidents and directors without any academic field. Some honorary members were there to provide political support. A few scholars in law, applied sciences, and theology complete the picture. 


\section{Place OF BIRTH}

Figure 2 is a plot of the places of birth of all the ordinary members of the Saint Petersburg Academy of Sciences. Many scholars came from Western and Central Europe, especially Prussia. This diversity led the language of the Academy to be Latin. Advantages were given to newly hired academicians to make Saint Petersburg attractive.

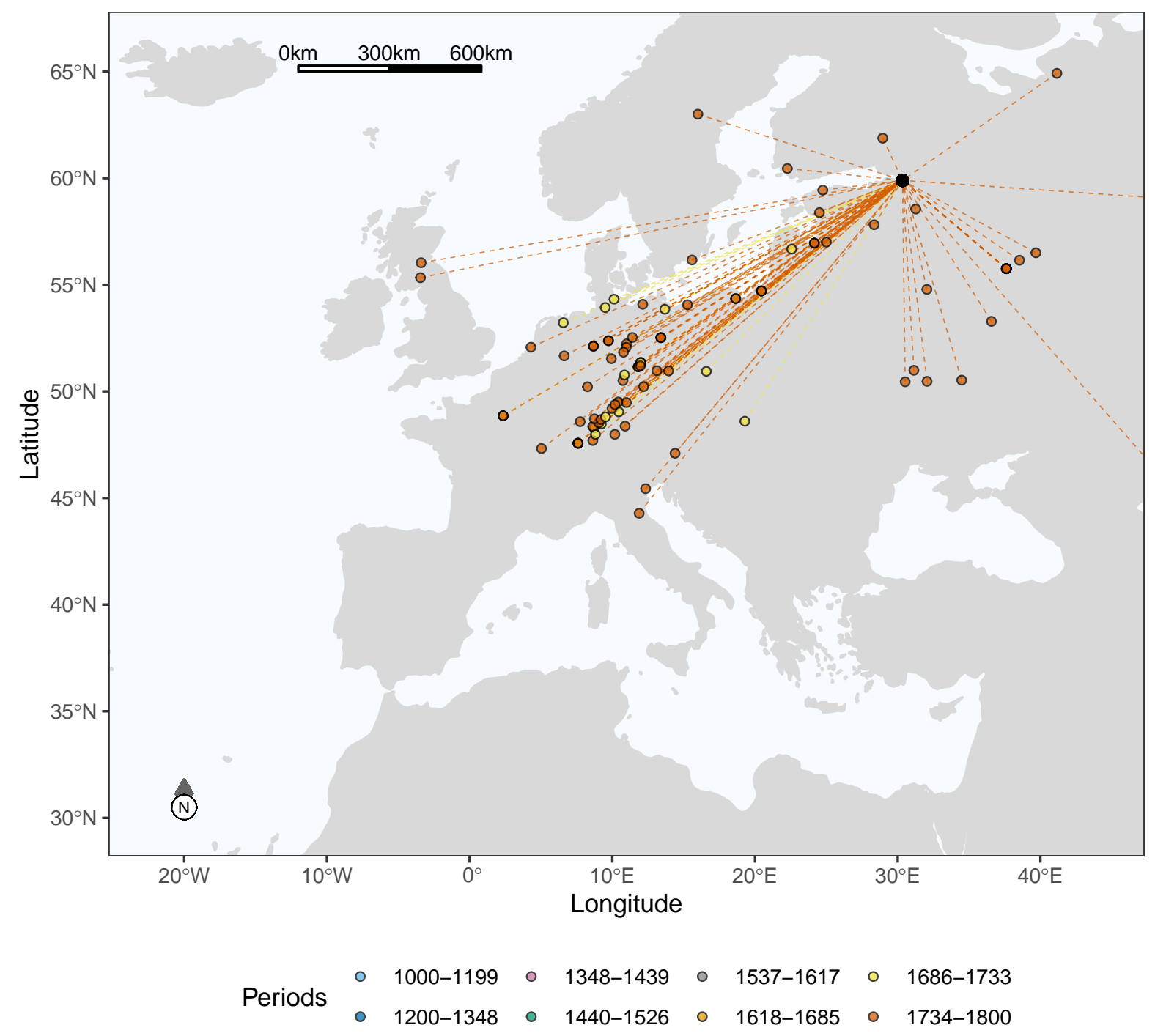

Figure 2: Places of birth of the scholars and literati at the Saint Petersburg Academy of Sciences Ordinary members

Figure 3 is a plot of the places of birth of the scholars of the Saint Petersburg Academy of Sciences who were external members. Still broadly dominated by German and French members, other European nationalities such as Italian and Spanish seem to have had links with the Academy. 


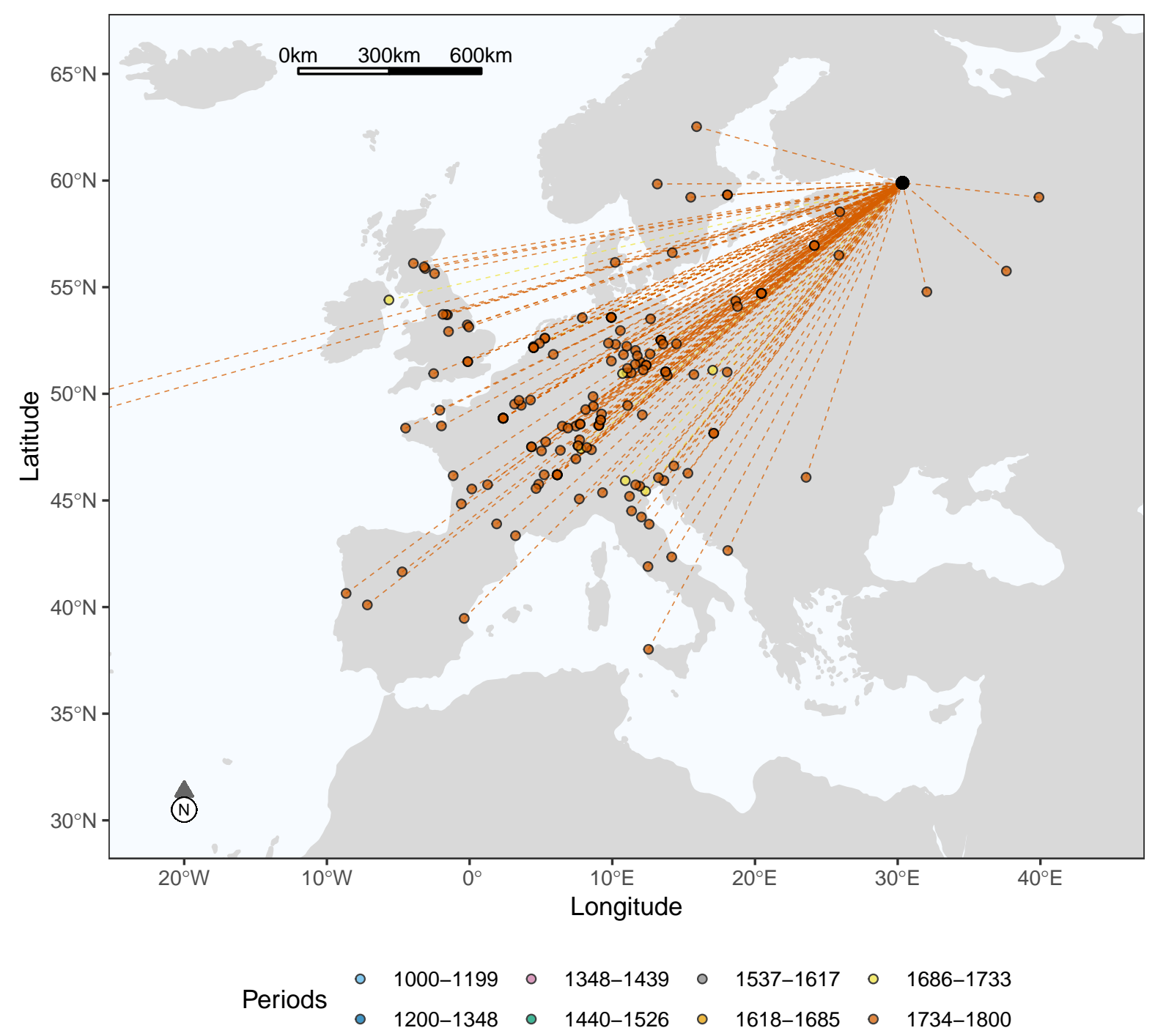

Figure 3: Places of birth of the scholars and literati at the Saint Petersburg Academy of Sciences External members

\section{HUMAN CAPITAL OF SCHOLARS AND LITERATI}

For each person in the database, we compute a heuristic human capital index, identified by combining information from Worldcat and Wikipedia using principal component analysis. The details are given in the Appendix. Figure 4 shows the names of all the scholars with a positive human capital index. The vertical green lines (rug plot) show the distribution of all scholars, including the obscure ones, over time. 


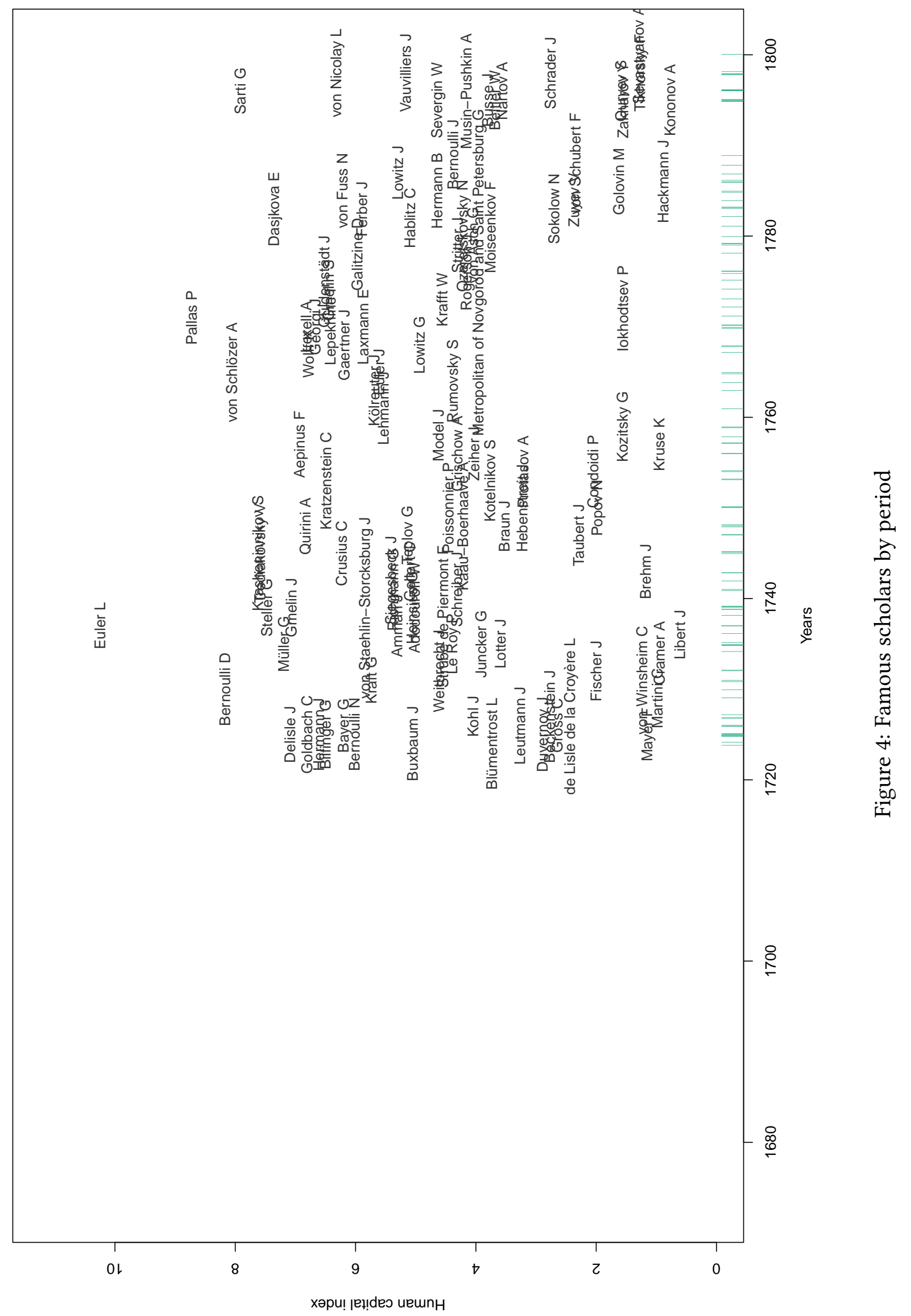




\section{TOP 5 MEMBERS}

We now provide a brief overview of the five ordinary members with the highest human capital index.

Leonhard Euler (Basel 1707 - Saint Petersburg 1783) was a mathematician, physicist, astronomer, and logician. He was called to Saint Petersburg by Daniel Bernoulli in 1727, with whom a noteworthy collaboration arose as he became an assistant in the mathematics department. Later, when Daniel Bernoulli left the Academy in 1733, Euler became the head of the mathematics department. He was also a professor at the University of Saint Petersburg (1727-1741). He left the city in 1741 to join the Royal Prussian Academy of Sciences, but returned in 1766 (De la Croix, Eisfeld, and Ganterer 2021). There he died in 1783 from a brain hemorrhage. The fame of the Saint Petersburg Academy is due in large part to him and his work. After Euler's death, the Academy honored him with a marble bust. In his eulogy, Condorcet complained that other Academies usually did not pay such respect to their own members (Euler 1859). Euler is considered as one of the greatest mathematicians of all time. He is known for his work on probability theory, calculus, graph theory, mechanics, and musical theory.

Peter Simon Pallas (Berlin 1741 - Berlin 1811) was a biologist, zoologist, and geographer. He was appointed professor of natural history at the University of Saint Petersburg and became an academician in 1767. He is known for his expedition across Russia to increase the state of knowledge in natural science. His work was to record all the types of species found during his expeditions and to analyze soil and water. The minerals collected during his expeditions are still on display in the museum of the Academy. Based on the works of Linnaeus and Buffon, he used the binomial system (genus - species) in his studies. However, he claimed that species were not definitively fixed and that their appearance could evolve, especially under the action of climatic factors.

Daniel Bernoulli (Groningen 1700 - Basel 1782) was a mathematician and physicist. He arrived in 1724 in Saint Petersburg with his brother Nicholas II, who had been appointed head of the mathematics department (1695-1726). Daniel held this position from 1728. He was also a professor at the University of Saint Petersburg (1724-1733). A friend of Leonhard Euler, he worked with him on various fields in mathematics and physics, developing significant theories such as the Euler-Bernoulli beam theory (1750). He and Euler shared the annual prize of the Paris Académie des Sciences ten times. He is also known for his contributions in statistics and probability (he offered a solution to the Saint Petersburg paradox), but also in fluid mechanics with his famous book Hydrodynamics (1738).

August Ludwig von Schlözer (Kirchberg-an-der-Jagst 1735 - Göttingen 1809) was a historian also known for some contributions in statistics. He was elected professor and academician in 1761. Gerhard Friedrich Müller, the official historian of the Russian court, called on him to collaborate. Schlözer became a professor at the Saint Petersburg Academy, but because of some disagreements and unsatisfactory material conditions, he decided to return to Göttingen. He continued his studies on Russian history and in 1770 published one of his most noteworthy works, the Nestorchronik, for which he was ennobled by Emperor Alexander I of Russia in 1804, thus becoming a private advisor to the latter. Eager to promote history as a more rigorous science, he developed statistical methods.

Giuseppe Sarti (Faenza 1729 - Berlin 1802) was a composer and conductor. After early successes in Italy, he was called to Copenhagen by King Ferdinand V in 1753. He remained in Denmark for twenty years, and in 1755 he held the position of Hofkapellmeister and director of the opera house. There he began to write operas in Danish. He was dismissed, it seems, for having bribed a public official, and returned to Italy. Catherine II, the empress of Russia, called him to her court in 1784 and appointed him academician in 1796. He dedicated the opera "Russian Oratorio" to the Russian prince Potemkin and "Armando e Rinaldo" and "The 
Early Reign of Oleg" to Catherine II, who wrote the libretto herself for the latter (Mamy 1987). At the Academy, he studied musical acoustics from a physical and mathematical perspective. He also put his many studies on acoustics to good use and invented a tuning fork with 436 vibrations known as the "Saint Petersburg reference" for tuning musical instruments. This reference is very close to the current one which is $440 \mathrm{~Hz}$ (Mozart used 432 vibrations, later defined as golden tuning because it is in tune with our organism and nature). Upon falling ill, he asked to return to Italy and Emperor Alexander I discharged him with a generous pension and a noble title. He died on his way back to Berlin on July 28, 1802.

\section{RELATED SCHOLARS}

Here, we provide a brief overview of the five external members with the highest human capital index.

François-Marie Arouet de Voltaire (Paris 1694 - Paris 1778) was a French philosopher, historian, and writer. He had a regular correspondence with Empress Catherine II, leading to a platonic love story. He was nominated a foreign member of the Academy in 1746. After Voltaire passed away, she acquired most of his volumes, which were then kept by the Saint Petersburg Library. Voltaire was a member of many academies throughout Europe such as the Royal Society, the Royal Prussian Academy of Sciences, and the National Academy of Sciences, Letters and Arts of Bordeaux (De la Croix and Dock 2021).

Immanuel Kant (Kaliningrad (Königsberg) 1724 - Kaliningrad (Königsberg) 1804) was a philosopher and a central figure of the Enlightenment. After becoming affiliated to the University of Königsberg in 1755, he joined the Prussian Academy in 1786 and became a foreign member of the Saint Petersburg Academy in 1794. His health deteriorated soon thereafter and we were not able to find much interaction between him and the Academy.

Benjamin Franklin (Boston 1706 - Philadelphia 1790) He is known as one of the Founding Fathers of the United States of America and as the discoverer of atmospheric electricity. He inspired Russian scholars to conduct experiments in this field. In collaboration with Mikhail Vasiljevich Lomonosov (1711-1765), Georg Wilhelm Richmann (1711-1753), an ordinary member of the Saint Petersburg Academy of Sciences and professor from 1737, carried out experiments in the field of atmospheric electricity. Richmann died during one of them. Franklin was in contact with Ekaterina Romanovna Dasjkova (1743-1810), whom he met in Paris in 1781 (DvoichenkoMarkoff 1947). She appointed him to the Academy and he thus became its first American foreign member in 1789. It is thanks to him that the first contacts were established between the American Philosophical Society and the Academy of Sciences of Saint Petersburg.

Denis Diderot (Langres 1713 - Paris 1784) was a materialistic philosopher and a prominent figure of the French Enlightenment. He was the editor-in-chief, with d'Alembert, of the Encyclopédie (De la Croix, Eisfeld, Ganterer (2021)). Following an invitation from Empress Catherine II, he travelled to Russia in 1773. He expressed his opposition to the autocratic behavior of the empress. He wrote the book "Les Observations sur l'instruction de Catherine II aux députés pour la confection des lois (1774)". He became a foreign member of the Academy in 1774.

Carl Linnaeus (Rashult 1707 - Uppsala 1778) was a physician and naturalist, a professor at the University of Uppsala since 1730. He spent his life building a classification system for plants and animals, which is still highly relevant today. He was nominated a foreign member of the Academy in 1753. Linnaeus carried out a lengthy correspondence with the academicians of Saint Petersburg, from whom he obtained significant information on Siberian flora. 


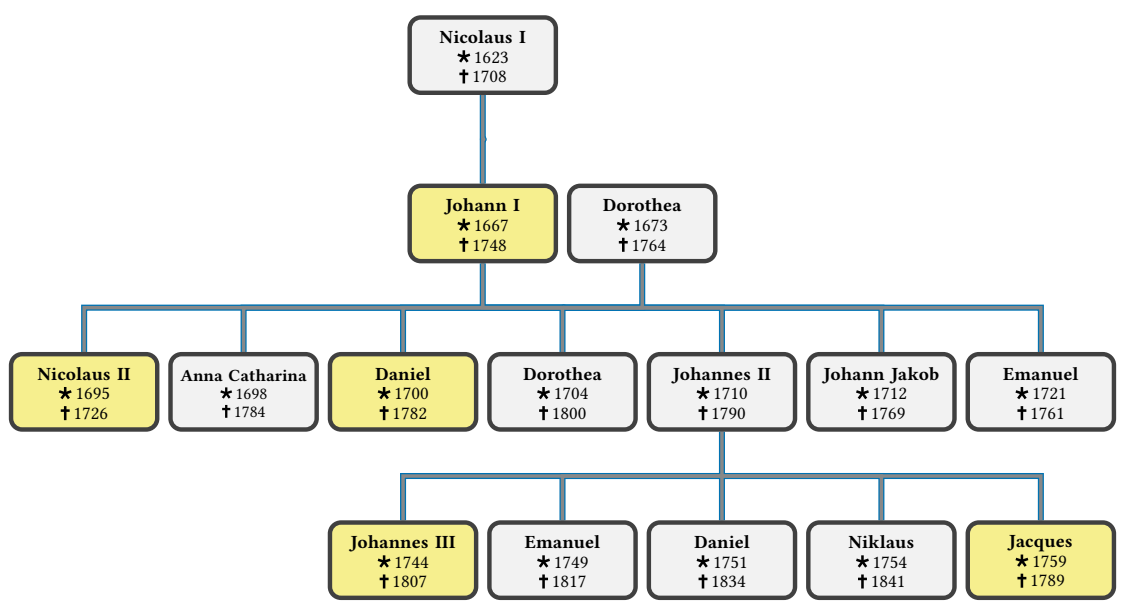

Figure 5: The Bernoulli family. Members of the Saint Petersburg Academy of Sciences in yellow squares

\section{FAMILIES OF SCHOLARS}

Figure 5 shows the Bernoulli family, with members of the Saint Petersburg Academy of Sciences before 1800 highlighted in yellow. Among the five scholars, four were ordinary members, while Johann I (1667-1748) was an external member. Among the children of Johann I, women as well as Johann Jakob (1712-1769) and Emanuel (1721-1761) were not scholars, the two latter being traders. Among the sons of Johannes II (1710-1790), Emanuel (1749-1817) and Daniel (1751-1834) were not scholars. All others mainly contributed to mathematics and physics.

\section{University of Saint Petersburg}

Figure 6 shows how many scholars were also professors at the University. Among 324 scholars, 71 were both professors and academicians. 253 of them were only academicians. The University of Saint Petersburg was part of the Academy when it was founded. Its aim was to train future scholars in a deficient Russian educational system, yet this department was not successful at first. In 1737, it had no students (McClellan, 1985). It led talented students to be sent abroad to Western European countries to be trained. This last point meant that the Academy was still quite dependent on other European countries.

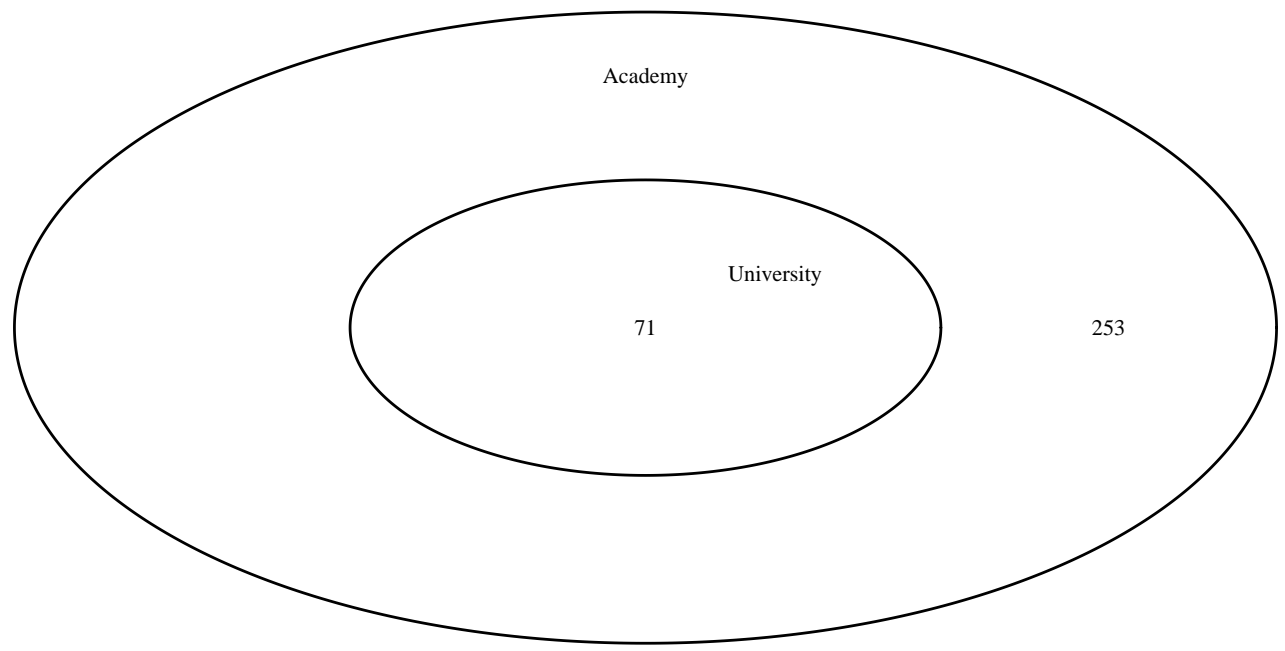

Figure 6: Intersection of the professors of the University of Saint Petersburg and the scholars of the Saint Petersburg Academy of Sciences 


\section{Diversity}

Ekaterina Romanovna Dasjkova (1743-1810) was the only woman who was a member of the Academy. Empress Catherine II appointer her director of the Academy from 1783 to 1794 (Shemivot 1873). She was one of the first women to be involved in the management of an academy. In 1783, she founded the Imperial Academy, which was devoted primarily to the study of the Russian language, literature, and culture. She also contributed to translating foreign books and texts into Russian. In 1783, she was elected an honorary member of the Royal Swedish Academy of Sciences. As a result of her contact with Franklin, she became the first female member of the American Philosophical Society (Dvoichenko-Markoff 1947).

\section{AnecDotes}

Johann Siegesbeck, a professor of Botany at the Russian Academy of Sciences and the director of the Botanical Gardens, ran into controversy with Linnaeus after the publication of his book "Botanosofia". In this work, he refuted Linnaeus's conclusion that plants have sexual differences. However, his demonstration was more moral than scientific. Linnaeus was offended and did not hesitate to take revenge. The Swedish scientist sent a package of seeds to Saint Petersburg. In the letter, he said he was sending Siegesbeck a new and very rare kind of plant, the "Cuculus ingratus" (ungrateful cuckoo) (Rowell 1980).

Ekaterina Romanovna Dasjkova was left a widow at 21 and decided to undertake a long journey across Europe. During her visit to Riga, she was shocked when she saw a painting in her room depicting the defeat of Russia. She is said to have spent the night changing the colors of military uniforms with her brush.

\section{APPENDIX}

The individual human capital index $q_{i}$ of an individual $i$ is given by:

$$
\begin{aligned}
q_{i}= & -1.76+0.43 \ln (\mathrm{nb} . \text { characters of the longest Wikipedia page }) \\
& +0.40 \ln (\mathrm{nb} . \text { Wikipedia pages in different languages })+0.47 \ln (\mathrm{nb} \text {. works in Worldcat }) \\
& +0.46 \ln (\mathrm{nb} \text {. publication languages in Worldcat })+0.47 \ln (\mathrm{nb} \text {. library holdings in Worldcat })
\end{aligned}
$$

We assume that having no Wikipedia page is similar to having one page with a length of 60 characters and that having no Worldcat page is similar to having a page with one work in one language held by one library. The constant -1.76 normalizes $q_{i}$ at 0 when there is neither a Wikipedia page, nor a Worldcat page. The weights $(0.43,0.40$, etc) are obtained from the first principal component of the five indicators (De la Croix et al. 2020).

\section{ACKNOWLEDGMENTS}

This project has received funding from the European Research Council (ERC) under the European Union's Horizon 2020 research and innovation programme under grant agreement No 883033 "Did elite human capital trigger the rise of the West? Insights from a new database of European scholars."

First version October 25, 2021. Updated 14 January 2022.

\section{REFERENCES}

De la Croix, David, and Fanny Dock. 2021. "Scholars and Literati at the National Academy of Sciences, Letters and Arts of Bordeaux (1712-1793)." Repertorium Eruditorum totius Europae 4:9-17.

De la Croix, David, Frédéric Docquier, Alice Fabre, and Robert Stelter. 2020. "The Academic Market and the Rise of Universities in Medieval and Early Modern Europe (1000-1800)." CEPR Discussion Paper 14509. 
De la Croix, David, Thomas Eisfeld, and Maximilian Ganterer. 2021. "Scholars and Literati at the Royal Prussian Academy of Sciences (1700-1800).” Repertorium Eruditorum totius Europae 3:1-9.

Dvoichenko-Markoff, Eufrosina. 1947. "Benjamin Franklin, the American Philosophical Society, and the Russian Academy of Science." Proc. Am. Philos. Soc. 91 (3): 250-257 (oct).

Euler, Leonhard. 1859. Lettres d'Euler à une princesse d'Allemagne sur divers sujets de physique et de philosophie accompagnées de l'éloge d'Euler par Condorcet... avec une introduction et des notes par Émile Saisset... Volume 1. Charpentier.

Lipski, Alexander. 1953. "The foundation of the Russian Academy of Sciences." Isis 44 (4): 349-354.

McClellan, James E. 1985. Science Reorganized: Scientific Societies in the Eighteenth Century. New York: Columbia University Press.

Rowell, Margery. 1980. "Linnaeus and botanists in eighteenth-century Russia.” Taxon 29 (1): 15-26.

Shemivot, Vladimir Petrovich. 1873. "General list of members of the Academy of Sciences since its foundation." St. Petersburg. 